in general. Hence the author concluded his last communica tion to the Chemical Society in the following words: "The difference in the nature of the elements of the same family group which is manifested in their regularly varying atomic weights, is also expressed in the similarly regular variation of the characters of the crystals of an isomorphous series of salts of which these elements are the interchangeable constituents."

A. E. Tutton.

\section{THE JACKSON-HARMSWORTH ARCTIC EXPEDITION.}

THE first meeting of the present session of the Royal Geographical Society took place at the Queen's Hall, Langham Place, on Monday night last, when Mr. Frederick G. Jackson lectured on the expedition led by himself to the Arctic regions. For the following abridged account of the lecture we are indebted to the Times:-

It was in August 1873 that the land afterwards known as Franz Josef Land was first accidentally discovered by the AustroHungarian expedition, under the leadership of Weyprecht and Payer. The following spring Payer made three journeys up and in the neighbourhood of what he then named Austria Sound. Arctic authorities advocated the route to the north suggested by Payer's impression that there was land still further to the north in and beyond the eighty-third degree, and land to the northwest reaching almost as far, and it was on Payer's observations that Mr. Jackson formulated his plans in the latter end of 1892 . Unfortunately his expectations were fated to disappointment by the non-extension of the land to the north. His plans embraced not only an advance in a northerly direction, but the mapping-in of the coast-lines of Franz Josef Land, a thorough examination of that country, in taking scientific observations, and making collections generally. Those plans they had been able to carry out; and scientific observations had been carried on uninterruptedly for three years. They had also practically completed the map of Franz Josef Land, and settled the Gillis Land question. For some time the sinews of war were conspicuous by their absence, and little encouragement was given, but eventually Mr. Alfred Harmsworth generously offered to provide the necessary funds for the proposed expedition. They left the Thames on July I2, 1894, in the steam yacht Windward, calling at Archangel. Then they proceeded east, skirting the northern shores of Kolguev Island to Kharborova, a Samoyed sattlement on the Yugor Straits, to take on board their thirty dogs and some fresh reindeer meat. They then steamed north through the Barents Sea, making for Bell Island, Franz Josef Land. The mass of islands of which Franz Josef Land was comprised con. sisted of high glacier-land rising to 2000 feet, covered with an ice. cap some hundreds of feet in thickness, and fronted along the shore by high perpendicularglacier faces from 30 feet to 80 feet in height. At rare intervals high black basaltic rocks jutted out of the ice near the shore, forming the only conspicuous landmarks. In front of these rocks the broken-down débris from the cliffs had formed a plateau, or shore, upon which a certain amount of stunted Arctic vegetation existed. Here might be found a few poppies, saxifrages, mosses, lichens, \&c. Everywhere else, with the exception of a few low islands, the ice-sheet overran everything. Thick mists generally overhung this land; violent gales were frequent, combined with heavily falling and driving snow. Finding no suitable site for their hut, they returned to Cape Flora, a high basaltic cape 1400 feet high, beneath which they pitched their camp, as being the most favourable spot they had yet seen, one of the strongest inducements being the presence of a large loomery there in the high rocks, and the known presence of bears and walruses throughout the year. This they reached on September 8. They at once set to work to shoot bears and walruses for the winter, and to put up their log hut, which was named "Elmwood," and to make themselves as comfortable as circumstances would allow. On the return of the sun, about the middle of February, they got ready to start, and on March $9 \mathrm{Mr}$. Armitage and he took a preliminary journey with the object of making a depôt of provisions to the north and of ascertaining the character of the travelling in that direction. In the beginning of April they got under way with three ponies and a number of sledges, being accompanied for the first week by Dr. Koettlitz and young Hayward with one pony and sledges. Soon after rounding Dundee Point they discovered that the existing maps were not quite in accordance with fact. To the northward lay floe ice where land had been mapped in ; and it was not till they reached the latitude of Point Arthur that they could discern land to the westward. To the south-west appeared open ocean. The weather now became very bad, anil they were frequently confined to their tent for days together. Constant gales and driving snow impeded their advance, and the floe ice itself became very unstable with water in the deeper layers of the snow, so that they were frequently wading about in slush above their knees. They, however, pushed on. Richthofen Peak could nowhere be discerned, and no hill worthy of the name of mountain could be seen in any direction, although they were within half a mile of its supposed site. On April 30 they rounded Cape Fisher, and to the north appeared a low island, which in the distance had rather a volcanic appearance, owing to a cup-shaped elevation upon it. On May I they rounded Cape $M^{\prime}$ Clintock, a low weathered cape of columnar basalt, projecting out of the ice-clad land behind. A striking feature of this rock was a pillar of columnar basalt standing up in front of it. Thus it was in April 1895 that they discovered the Queen Victoria Sea, which he named after her Majesty. They reached a point $8 \mathrm{I}^{\circ} 2 \mathrm{O}^{\prime} \mathrm{N}$. They carefully mapped in the whole coast-line, although the weather was exceedingly unsuitable for taking bearings. On May 4 they started back in a strong wind, dense mist, and driving snow, returning by the same route as they had come up. The difficulties of the floes daily increased. They had constantly to hanl the ponies out of the snow morasses with ropes round their necks. They would then go for a few yards further and would flounder in again. They frequently had to take the sledges on themselves, leading the ponies through especially bad places, and had to go over the same ground thirteen times to effect this. On their return journey they got a view of the land to the north-west, which appeared to consist of islands. They returned again round the cape that he had named Cape Richthofen. thus giving themselves an opportunity of discovering the whereabouts of Richthofen Peak, if such existed; but they again failed to see any sign of such a hill in any direction. On May I 2 they reached their hut at Cape Flora, getting the ponies back in the nick of time. After their return they were busy with botanical, geolngical. and other examinations, and in fitting up their whaleboat, the Mary Harmsworth, for a journey round the south-west coast as soon as the Windzerard should break loose from her wi, ter quarters and depart for home. This she did on July 3, after being cut out of the ice. To the southward there appeared to be little ice, and from an altitude of over I 400 feet litıle more than open sea could be discerned. The other expeditions made by Mr. Jackson during his stay were described, and the lecturer concluded by saying that, so far from viewing Franz Josef Land as a favourable route to the Pole, his experiences now led him to believe it to be one of the worst; and although he had, in common with other Arctic explorers, the greatest desire to stand upon that mathematical point, still he had no sympathy with an attempt to reach the Pole as a mere athletic feat alone, but considered that geographical and other scientific work should always be included in the plan.

\section{REPORT ON TECHNOLOGICAL EXAMINATIONS.}

THE report on the work of the Examinations Department of the City and Guilds of London Institute for the session I 896-97 has just reached us, and is as usual a very business-like and interesting publication. We make a few extracts from it.

There has been a marked development in the work of the Examinations Department of the Institute during the past Session, as shown not only in the larger number of classes in Technology registered by the Institute, but also in the increase in the number of students in attendance at such classes, and of candidates for examination. This development is due to the further provision of facilities for technical instruction, and also to the fuller recognition of its value and importance.

The report before us shows that the Institute has endeavoured in various ways to assist this forward movement

Since the Technological Examinations were first undertaken by the Institute, the organisation of technical instruction has been greatly promoted by the Educational Committees of County Councils, with which the Institute has established close relations; and many of the improvements, which have been introduced into its schemes of instruction and examination, have been due

No. I 463, vOL. 57$]$ 
to the suggestions of the organising secretaries of those committees.

In London, through its representation on the Technical Education Board of the London County Council and on the London Polytechnic Council, the Institute has taken a large share in the direction and organisation of the educational work of the Poly. technic Institutions ; and in accordance with the original scheme of the Charity Commissioners for the administration of those bodies, the examinations of the Institute have been generally adopted, and the instruction given in those Institutions, although in no way unduly subordinated to examination influences, has been legitimately, and, it is believed, usefully, directed by the Institute's requirements.

During the session under review the number of students in attendance at the classes registered by the Institute was 32,566 , as against 29,494 in the previous year, and the number of candidates' papers examined was 12,868 , as against 12,099 .

To enable the Institute to adapt its schemes of instruction to local needs and to the changing requirements of different trades, and to make its examinations a true test of the technical knowledge and ability of the artisan students who have been trained in its registered classes, frequent changes are made in its syllabuses of instruction, and tests of workmanship, wherever practicable, are made a part of the examination. Several alterations have been made in the programme of instruction and examination for the session 1897-98, to some of which we draw attention. Thus, in the syllabuses of textile subjects, important changes have been introduced.

Reference was made in last year's report to a discussion by a committee of experts in Lancashire of the conditions of examination in cotton weaving. The report of that committee was received by the Institute early in the session, and subsequently a conference was held in London of representatives of the Institute, the Institute's examiners and inspector, and delegates from the Technical Instruction Committee of the Manchester County Council. As a result of that conference, it was proposed that a new syllabus should be prepared in several of the weaving subjects to cover a period of three years, and that the full certificate should be granted to those students only who complete the three years' course of study. It was also considered advisable that candidates, before entering upon their first year's course of technical instruction, should pass a preliminary examination in the subjects of arithmetic, drawing, and elementary physics, in their special application to the technology of spinning and weaving. The representatives of the Union of Lancashire and Cheshire Institutes, having undertaken to prepare and submi for approval to the Committee of the Institute a syllabus of in struction for this preliminary examination, the Institute decided, after carefully considering the syllabus, to accept the certificate of the Union in lieu of the certificates of the Science and Art Department, previously required to qualify for a full technological certificate. New syllabuses were accordingly prepared in cotton spinning and weaving, in wool and worsted spinning and weaving, and also in jute spinning and weaving; and these syllabuses, after being modified by different experts to whom they were submitted, were finally adopted by the Institute, and have been inserted in the Programme. To obtain a certificate in the ordinary grade of either branch of calico or cloth manufacture, it will now be necessary that the student, unless specially exempted, should go through a two years' course of study and pass an examination at the end of each year's work.

In the subject of iron and steel manufacture, a new syllabus has been written; and with the view of adapting the examin. ation to the requirements of students working in different parts of the country, a large number of questions will be given, covering the different sections into which the syllabus has been divided, and candidates will be at liberty to select those questions bearing upon the practice of the trade in the district in which they work.

It has been thought desirable to limit the scope of the examination in the electro-metallurgy to the principles underlyin the electro-deposition of metals, and in order to bring the instruction into closer touch with the requirements of students engaged in the manufacture of electro-plated goods, the syllabus of examination has been modified, and the title of the subject has been changed into that of "Electro-Plating and Deposition.'

The syllabus in mine surveying has been re-written with the view of making the instruction and examination more distincily technical than hitherto. Questions will be set involving a know- ledge of logarithms and trigonometry, and of the application of trigonometry to problems in mine surveying; but the questions in pure mathematics, which previously formed a part of the examination, will be omitted.

The report, in addition to giving particulars as to the various examinations which took place in connection with the session, contains extracts from statements made by the examiners concerning the general character of the work examined, which should prove useful to both teachers and students.

\section{EXPERIMENTAL MORPHOLOG $Y{ }^{\circ}$}

$\mathrm{I}$ looking at the progress which has been made in the study of plant morphology, $I$ have been as much impressed with the different attitudes of mind toward the subject during the past I 50 years as by the advance which has taken place in methods of study, as well as the important acquisitions to botanical science. These different view points have coincided to some extent with distinct periods of time. What Sachs in his "History of Botany" calls the "new morphology" was ushered in near the middle of the present century by von Mohl's researches in anatomy, by Naegeli's investigations of the cell, and Schleiden's history of the development of the flower. The leading idea in the study of morphology during this period was the inductive method for the purpose of discerning fundamental principles and laws, not simply the establishment of individual facts, which was especially characteristic of the earlier period when the dogma of the constancy of species prevailed.

The work of the "herbalists" had paved the way for the more logical study of plant members by increasing a knowledge of species, though their work speedily degenerated into mere collections of material and tabulations of species with inadequate descriptions. Later the advocates of metamorphosis and spiral growth had given an impetus more to the study of nature, though diluted with much poetry and too largely subservient to the imagination, and to preconceived or idealistic notions.

But it was reserved for Hoffmeister (I859), whose work followed within three decades of the beginnings of this period, to add to the inductive method of research, as now laid down, the comparative method; and extending his researches down into the Pteridophyta and Bryophyta, he not noly established for these groups facts in sexuality which Camerarius and Robert Brown had done for the Spermatophyta, but he did it in a far superior manner. He thus laid the foundation for our present conceptions of the comparative morphology of plants. Naegeli's investigations of the cell had emphasised the importance of its study in development, and now the relation of cell growth to the form of plant members was carried to a high degree, and it was shown how dependent the form of the plant was on the growth of the apical cell in the Pteridophyta and Bryophyta, though later researches have modified this view; and how necessary a knowledge of the sequence of cell division was to an understanding of homologies and relationships. Thus in developmental and comparative studies, morphology has been placed on a broader and more natural basis, and the homologies and relationships of organs between the lower and higher plants are better understood.

But the growth of comparative morphology has been accompanied by the interpretation of structures usually from a teleological standpoint, and in many cases with the innate propensity of the mind to look at nature in the light of the old idealistic theories of metamorphosis.

I wish now to inquire if we have not recently entered upon a new period in our study of comparatlve morphology. There are many important questions which comparative studies of development under natural or normal conditions alone, cannot afford a sufficient number of data. We are constantly confronted with the problems of the interpretation of structure and form, not only as to how it stands in relation to structures in other plants, which we deal with in comparative morphology, but the meaning of the structure or form itself, and in relation to the other structures of the organism, in relation to the environment, and in relation to the past. This must be met by an inquiry on our part as to why the structure or form is what it is, and what are the conditions which influence it. This we are

1 Address delivered before Section G (Botany) of the American Associa tion $f \mathrm{r}$ the Advancement of Science, at Detrolt, by Prof. G. F. Atkinson. address, but bibliographical references

$$
\text { No. } 1463 \text {, voL. } 57]
$$

